\title{
LOGOS, ETHOS DAN PATHOS DALAM ILMU MANAJEMEN PEMASARAN
}

\section{LOGOS, ETHOS AND PATHOS IN THE SCIENCE OF MARKETING MANAGEMENT}

\author{
Helidorus F. Anin ${ }^{1}$ \\ aninherry04@gmail.com \\ Desmon Redikson Manane ${ }^{2}$ \\ desmonm23@gmail.com \\ ${ }^{12}$ Fakultas Ekonomi dan Bisnis Universitas Timor
}

\begin{abstract}
The study aims to point out the dimensions of the logos, ethos and pathos in the science of marketing management. These three dimensions are essential to reconstructing scientific theories that withstand trials. As for the knife analysis used in this analysis isa scientific philosophy with methodical elements, which is on interpretation, internal coherence and deskprisi. Studies indicate that the dimension of the logos was contained in evolution definition of marketing down through time. The technical dimensions of marketing eventually found its profounder model when it made the social capital a universal logos, enabling it to be generalized and supported by the facts that surrounds it. The ethos dimension is based on efforts to make social capital a core business, which makes it easier to reconstruct trust schemes in the long term and privacy that reflect customers' image. Pathos dimensions can be identified via art identifying values, providing value and communicating values transformations from customer needs.
\end{abstract}

Keyword: logos, ethos, pathos, marketing

\begin{abstract}
Abstrak
Penelitian ini bertujuan untuk menunjukkan dimensi logos, ethos dan pathos dalam ilmu manajemen pemasaran. Ketiga dimensi ini mutlak perlu untuk mengonstruksi teori ilmiah yang tahan uji. Adapun pisau analisis yang digunakan dalam analisis ini adalah filsafat ilmu dengan unsur-unsur metodis, yaitu pada interpretasi, koherensi intern dan deskprisi.Hasil penelitian menunjukkan bahwa dimensi logos terkandung dalam evolusi pendefinisian pemasaran sepanjang zaman. Dimensi keilmuan pemasaran akhirnya menemukan modelnya yang tahan uji ketika menjadikan social capital sebagai logos universal sebab bisa digeneralisasi dan didukung oleh fakta yang mengitarinya. Dimensi ethos terdapat dalam upaya untuk menjadikan social capital sebagai core business sehingga memudahkan dalam mengonstruksi skema jaminan kepercayaan dalam jangka panjang dan kekhasan yang menunjukkan citra pelanggan. Dimensi pathos dapat diidentifikasi melaui seni mengidentifikasi nilai, menyediakan nilai dan mengkomunikasikan nilaiyang ditransformasi dari kebutuhan pelanggan.
\end{abstract}

Kata kunci: Logos, Ethos, Pathos, Pemasaran 


\section{Pendahuluan}

Pokok persoalan yang ada dalam manajemen pemasaran seturut kaca mata keilmuan modernadalah belum ditemukannya konsep umum tentang pemasaran. Hunt sebagaimana dikutip Setyawan (2012) menunjukkan bahwa hingga saat ini ilmu marketing belum menurunkan hipotesisnya dari sebuah hukum empirik yang berlaku universal. Selain itu, ilmu marketing belum menunjukkan aspek sosialnya padahal marketing bertolak dari ilmu ekonomi yang sesungguhnya bersifat sosial. Dengan dasar pemikiran ini, diusulkan agar para pakar marketing baik ilmuan maupun praktisi berusaha memperluas konsep marketing agar bisa menemukan konsep yang berlaku universal.

Argumentasi yang diungkapkan di atas benar di satu pihak tetapi kurang memadai di pihak lain. Argumen itu benar sebab hingga saat ini penelitian-penelitian tentang marketing hanya menghasilkan kesimpulan yang kontradiktif yang kemudian melahirkan hipotesis yang berbeda pula. Dengan kata lain, peneliti marketing mengalami kesulitan untuk menggeneralisasikan teorinya sebab hasil penelitian datang dari lingkup yang sempit atau parsial. Sebagai contoh: peneliti tertentu menunjukkan bahwa supaya perusahaan atau organisasi dapat bertahan secara jangka panjang, maka manajemen harus memproduksi barang sebanyak-banyaknya untuk dialurkan kepada sebanyak-banyaknya orang. Tetapi ada juga peneliti yang berkesimpulan bahwa keberlanjutan suatu perusahaan hanya bisa bertahan jika mengandalkan modal sosial. Dan ada juga yang berpendapat bahwa keunggulan bersaing suatu perusahaan hanya bisa dicapai manakala perusahaan gencar untuk melakukan promosi kepada sekian banyak pelanggan. Intinya, banyaknya variabel yang berbeda dalam penelitian dan hipotesis marketing itulah yang menyebabkan kesulitan untuk menentukan fondasi teori ilmiah (Lukitaningsih, 2013).

Terlepas dari begitu banyaknya varian hipotesa yang ada, ilmu marketing telah mengupayakan semangat objektivitasnya. Ilmu marketing telah secara jelas menentukan bahwa pelanggan sebagai subjek dan sasaran penelitian. Marketing bergerak dari permintaan yang datang dari pelanggan dan pada akhirnya mengambil keputusan untuk memberi kepuasan bagi pelanggan. Keuntungan dalam arti material hanya dianggap sebagai umpan balik dari objektivitas keilmiahan ilmu marketing itu sendiri. Para ilmuan marketing mulai muncul kata sepakat bahwa teori umum yang dapat diturunkan untuk membuat penelitian adalah social capital. Hal ini menunjukkan bahwa marketing tidak saja menerapkan semangat objektivitas tetapi ada pula wajah sosial yang ditampakkan sehingga terdapat spirit intersubjektivitas atau komunikasi dua arah antara perusahaan dan pelanggan.

Merujuk pada pendapat Imre Lakatos, ilmu marketing bisa disebut ilmiah karena telah berusaha untuk mengakomir fakta di sekitarnya bahkan menemukan fakta baru (Poepowardojo dan Seran, 2016: 115). Karena itu, tulisan ini berusaha untuk menunjukkan dimensi logos, ethos dan pathos dari ilmu marketing sebagai sinyalemen bahwa perbedaan hipotesa bukanlah alasan untuk membatalkan keilmiahan teori tertentu. Yang terpenting dalam penelitian adalah prosedur logis yang ditempuh untuk mencapai sebuah bangunan teori yang ilmiah. 


\section{Metode}

Penelitian ini merupakan studi kepustakaan. Data dikumpulkan berdasarkan kepustakaan yang tersedia sambil memperhatikan relevansi dengan topik yang dibahas. Data yang tersedia kemudian diolah dengan metode sistematis reflektif yang fokus pada interpretasi, koherensi intern dan deskprisi.

\section{Pembahasan}

\section{Sejarah Perkembangan Ilmu Manajemen Pemasaran}

Revolusi industri yang terjadi pada tahun 1900 disinyalir sebagai suatu momentum yang menjadi cikal bakal lahirnya konsepsi tentang manajemen pemasaran. Sinyalemen ini menjadi penting sebab pada momentum revolusi industri terjadi pergeseran aktivitas bisnis yang sebelumnya berciri merkantilis berubah menjadi kapitalis. Konkretnya, pada era merkantilisme semua orang terlibat di dalam kegiatan untuk memperdagangkan kekayaan alam di wilayahnya. Sedangkan era kapitalis, kegiatan ekonomi dikendalikan oleh pemilik modal. Yang paling mencolok di sini adalah: orang-orang yang memiliki modal yang cukup mulai membangun pabrik dan organisasi perusahaan kemudian memproduksi barang dalam jumlah yang banyak dan memperdagangkannya kepada sebanyak-banyaknya orang. Di sini, marketing dilihat sebagai salah satu bentuk dari aktivitas ekonomi.

Dalam perkembangannya, orang mulai mempertanyakan tentang bagaimana keberlanjutan organisasi/ perusahaan yang dibangunnya itu. Sasaran pertanyaan ini adalah menjawab persoalan tentang perilaku yang terjadi di pasar dan bagaimana perusahaan merespon kebutuhan pasar. Persoalan inilah yang kemudian mendorong para pakar untuk membangun konsepsi-konsepsi tentang pemasaran. Intinya ialah pemilik perusahaan dan para pakar tidak lagi menyadari marketing sebagai salah satu aktivitas bisnis tetapi mengembangkan marketing sebagai strategi untuk mempertahakan keberlanjutan perusahaan dengan memperkirakan keuntungan jangka panjang.

Reaksi untuk mengembangkan konsepsi marketing nampak dalam upaya memasukkan marketing sebagai bahan ajar di dalam lingkup pendidikan formal. Kelas pertama dari pelajaran marketing diberikan oleh ED Jones pada tahun 1902 di University of Michigan kemudian oleh Simon Litman di University of California pada tahun yang sama. Meskipun demikian, isu kunci yang diajarkan lebih fokus pada masalah distribusi sebab konteks bisnis pada saat itu memang mengarah pada distribusi massal barang-barang produksi. Dalam perkembangannya, konsepsi-konsepsi marketing banyak berkembang di seperti Wisconsin, Harvard, Ohio State, University of Illinois dan Northwestern University. Perkembangan yang dimaksudkan adalah para ahli mulai mempertimbangkan untuk menganalis kembali konsep advertising (periklanan) yang sebelumnya telah dikembangkan pada tahun 1875 dalam buku History of Advertising. Hal ini juga berlaku dengan konsep selling yang berkembang sebelumnya dianalis dan dikembangka tidak hanya sebagai seni menjual tetapi sebagai formula khusus dalam keilmuan tentang marketing. Dengan demikian, marketing sejak awal hanya berurusan dengan tiga konsep kunci, yaitu: adevrtising, selling dan distribution.

Pada tahun 1920-an, Paul Ilvey meluncurkan satu buku tentang Principles of Marketing. Kemudian, muncul pula buku berikut yang lebih terkenal tentang Principles of Marketing yang dikarang oleh Maynard, Weidler dan Beckman. Yang berbeda dari dua isi 
buku ini adalah:Principles of Marketing karang Paul Ilvey lebih berfokus pada pengusaha, sedangkan Maynard, Weidler dan Beckmanlebih berfokus pada sudut pandang konsumen. Pada dekade-dekade berikutnya mulai bermunculan masuk-masuknya ilmu-ilmu lain seperti psikologi dan sosial untuk memperkaya marketing (Lukitaningsih, 2013).

Elemen-elemen dalam marketing sendiri mengalami perkembangan. Sebagai contoh, ilmu advertising semakin berkembang dengan masuknya media-media baru seperti televisi yang mulai populer pada tahun 1960-an. Pada tahun 1960-an dan 1970-an ilmu marketing justru memecahkan diri ke dalam berbagai diferensiasi (kekhususan) seperti international marketing, social marketing, marketing for non-profit organization dan lainlain. Konsep social responsibility juga menjadi salah satu konsep yang sudah mulai terbentuk pada tahun 1970 (Kotler dan Keller, 2009: 20).

Kejayaan Kotler sebagai "bapak marketing" sendiri dimulai pada periode 1970-an. Peran Kotler dalam dunia marketing memang pada kemampuannya menerjemahkan konsep marketing ke terminologi yang mudah dipahami oleh banyak orang. Kotler-lah yang mengubah konsep marketing ke bentuk-bentuk aplikasi tertentu seperti marketing untuk health service, public service, educational service, politik, dan lain-lain.

Tahun 1967, misalnya, Kotler sudah memperkenalkan konsep manajemen marketing modern yang meliputi analisis marketing opportunities, mengorganisasikan aktivitas marketing, kegiatan perencanaan marketing serta kontrol. Buku-buku Kotler kemudian menginspirasi banyak para pengajar dan praktisi di dunia marketing seluruh dunia. Bahkan, tak ada kuliah marketing yang tak lepas dari karya-karya Kotler. Buku Principles of Marketing dan Marketing Management dari Kotler membentuk pemikiranpemikiran dasar dan fundamental yang mempengaruhi berbagai pemikiran baru lainnya di dunia marketing.

Pada dekade 1980-an, pemikiran baru di dunia marketing seperti positioning yang dipopulerkan oleh Jack Trout dan Al Ries serta brand equity yang dipopulerkan oleh David Aaker semakin menguat. Era kemajuan bisnis di banyak negara pada dekade tersebut menciptakan kompetisi bisnis yang semakin ketat. Karenanya, peran dari sebuah merek dan upaya untuk mendiferensiasikan diri juga mengemuka. Dekade 1980 dan 1990-an adalah dekade menguatnya unsur service dan kepuasan pelanggan di dalam marketing. Konsep seperti Servqual, Service profit chain dan juga services marketing mulai bermunculan.

Ketika dunia memasuki gelombang revolusi berikutnya, yakni revolusi teknologi informasi, maka pemikiran-pemikiran marketing baru pun bermunculan mengikuti gelombang revolusi tersebut. Salah satunya konsep experiential marketing. Dengan adanya teknologi informasi, internet dan multimedia membuat experiential marketing lebih bisa berkembang. Demikian pula di dunia service, peran IT membuat konsep CRM (Customer Relationship Management) juga ikut berkembang. Belum lagi jargon-jargon baru seperti buzz marketing, viral marketing dan lain-lain (Kotler dan Keller, 2009: 23).

Tentu saja, seiring dengan revolusi ini, maka marketing pun harus berubah dalam cara memandang kompetisi. Aliansi dan co-branding adalah cara memandang kompetisi baru, di mana kerja sama dengan segenap pihak, termasuk kompetitor bisa menjadi kunci kemenangan. Juga konsep "blue ocean" yang mendesak para marketer untuk menciptakan kompetisi yang baru daripada bersaing di pasar yang sudah semakin sesak. 
Revolusi baru juga berimbas pada perkembangan media periklanan. Semakin berkembang dan kompleksnya media untuk berpromosi membuat marketer semakin berhati-hati menginvestasikan dananya. Oleh karena itu muncul pemikiran-pemikiran baru yang menggugah. orang marketing untuk menghitung return on investment dari aktivitas marketing yang dilakukannya. Marketing dihadapkan pada kenyataan bahwa kegiatan mereka harus mampu dijelaskan dengan bahasa-bahasa finansial. Marketing ROI, CLV (Customer Lifetime Value), dan lain-lain adalah pemikiran-pemikiran yang kemudian mulai muncul.

Dari berbagai pergolakan pemikiran marketing tadi kita bisa menyimpulkan bahwa pemikiran marketing, mau tidak mau, harus terus berubah dan berkembang sesuai dengan perubahan struktural yang terjadi dalam tatanan sosial ekonomi masyarakat, bentuk dan tingkat kompetisi yang ada serta perkembangan teknologi. Setelah revolusi industri dan IT, dunia diramalkan akan masuk ke revolusi bioteknologi.

\section{Identifikasi Logos dalam Manajemen Pemasaran}

Logos dalam Yunani diartikan sebagai ucapan; pembicaraan; pikiran; akalbudi; kata; arti; studi tentang; pertimbangan tentang; ilmu pengetahuan tentang; alasan pokok mengapa suatu hal adalah apa adanya; prinsip-prinsip dan metode-metode yang digunakan untuk menjelaskan gejala-gejala dalam suatu disiplin tertentu; aspek-aspek di dalam suatu benda yang membuat benda itu dapat kita mengerti; dasar pemikiran tentang suatu hal. (Bagus 2005: 543-544).

Sejak awal, para marketing baik ilmuan maupun praktisi berkutat dengan persoalan: bagaimana organisasi/ perusahaan mempertahankan sustainabilitas jangka panjangnya? Persoalan ini mengandung dua konsekuensi penting, yaitu: organisasi/ perusahaan dan kata "bagaimana". Pertama, organisasi/ perusahaan diniscayakan sebagai fakta yang sudah ada sehingga tugas marketing adalah berusaha menjaganya agar tetap bertahan. Kedua, mengajukan pertanyaan dengan kata kunci "bagaimana" menuntun ilmu marketing berusahameemukan solusi praktis dengan tujuan menciptakan kondisi bagaimana perusahaaan seharusnya ada. Sejatinya, marketing sebagaimana ilmu-ilmu lain berpijak pada urusan das sollen dan das sein.

Jawaban terhadap persoalan tentang bagaimana organisasi/ perusahaan mempertahankan sustainabilitas jangka panjangnya berlangsung cukup lama dan berkembang sesuai konteks jaman (Ferdinand, 2005: 11-13). Defini pertama tentang marketing diperkenalkan oleh National Association of Marketing Teachers sebuah organisasi pendahulu dari AMA - American Marketing Association pada tahun 1935 sebagai berikut :" Marketing is the performance of business activitites that direct the flow of goods and services from producers to consumers". Definisi ini tentunya memberi jawaban bahwa supaya perusahaan dapat bertahan dalam jangka panjang, maka dia harus fokus pada produksi barang sebanyak-banyaknya untuk kemudian dijual kepada konsumen. Meskipun demikian, definisi ini kelihatan menyisakan kesulitan besar, yaitu: seperti terbatas pada kegiatan bisnis dengan mengabaikan asas universalisnya, fokus pada pemasar dan konsumen dengan mengabaikan proses pengambilan keputusan, bergerak hanya satu arah yaitu "producer to consumer or user", pada realitas menunjukkan dua arah yang interaktif. 
Jawaban kedua terhadap persoalan pokok persoalan marketingdikembangkan oleh American Marketing Association (AMA) pada tahun 1985 yang mendefinifikan marketing sebagai :" The process of planning and executing the conception, pricing, promotion, and distribution of ideas, goods and services to create exchange that satisfy individual and organizational goals". Definisi ini memberi solusi bahwa supaya perusahaan dapat bertahan, maka dia harus menciptakan hubungan pertukaran muatan nilai yang saling menguntungkan dengan pelanggan. Dalam prakteknya definisi ini juga menunjukkan beberapa kekurangan seperti fokus hanya pada hubungan antara organisasi dan konsumen mengabaikan B2B (Busines to business) yang melibatkan dua atau lebih organisasi, berorientasi pada produksi, kurang memperhatikan pemasaran global, fokus pada perspektif manajerial kurang pada perspektif sosial dimana peranan pemasaran dalam masyarakat diabaikan.

Perlunya perbaikan terhadap berbagai keterbatasan itu mendorong AMA meredefinisi pemasaran pada tahun 2004 sebagai berikut: " Marketing is an organizational function and a set of process for creating, communicating and delivering value to customers and for managing customer relationship in ways that benefit the organization and its stakeholders". Perubahan definisi ini membuat marketing lebih memiliki wajah sosial yang dibutuhkan masyarakat saat ini dimana terjadi pergeseran menuju sebuah fungsi organisasi yang strategis, berorientasi pada value proposition berupa penawaran total untuk memenuhi kebutuhan, preferensi dan ekspektasi sehingga tercapai satisfaksi, bersifat "customer centric", yang tidak sekedar dipusatkan pada "exchange" tetapi lebih lebih pada "relationship" dengan cakrawala waktu yang panjang.Dengan wajah sosial yang seperti ini, peran pemasaran membutuhkan bekerjanya instrumen-instrumen manajemen yang lebih berwajah sosial dan dalam kaitan inilah modal sosial menjadi sangat relevan sebagai salah satu instrumen strategis yang ikut mewarnai berbagai proses manajemen untuk menghasilkan keunggulan bersaing dan karenanya menjadi intrumen untuk menghasilkan kinerja yang berkelanjutan. berikut:

Evolusi logos sepanjang perkembangan keilmuan marketing dapat digambar seperti

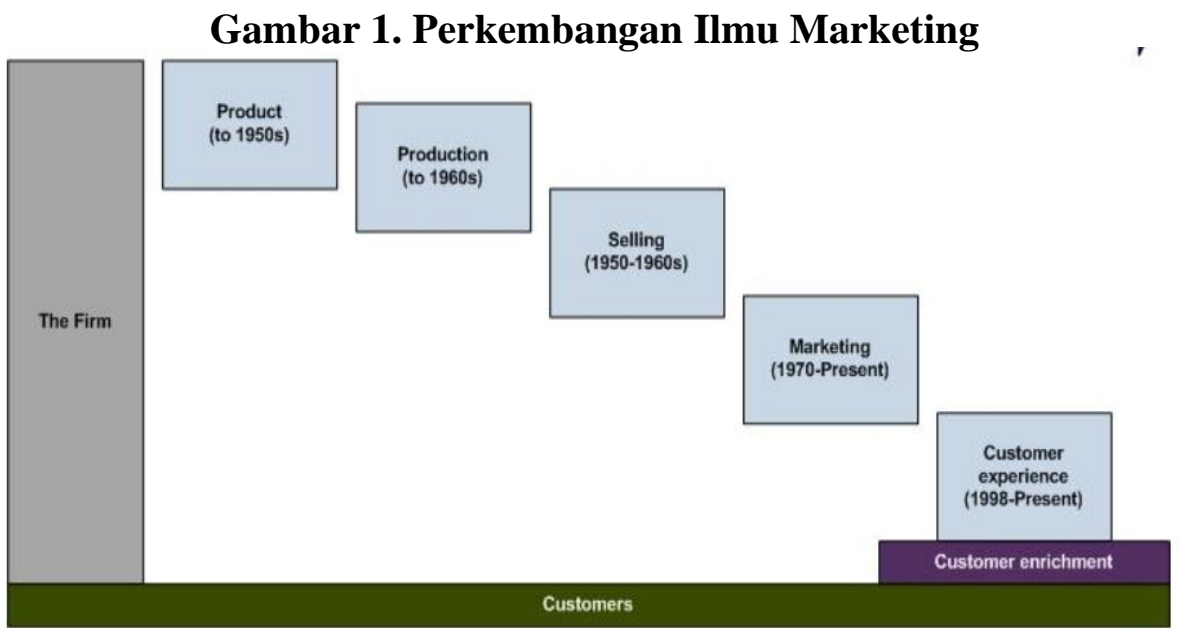

Sumber: http://www.google.co.id/The_Evolution_of_Marketing/wikipedia.org 
Kotler dan Amstrong (2008: 11-14) menunjukkan bahwa logos di dalam ilmu marketing bergerak dengan empat dasar filosofi, yaitu: Pertama, konsep produksi yang didasarkan pada ide bahwa biaya rendah adalah yang paling penting, dan tugas manajemen adalah berkonsentrasi pada volume produksi dan efisien untuk menurunkan biaya dan harga. Kedua, konsep produk dimana konsumen akan memilih produk yang bermutu tinggi dan bahwa jika produksinya cukup bagus, hanya sedikit usaha promosi yang diperlukan. Ketiga, konsep penjualan dimana sebuah perusahaan meraih keunggulan bersaing dengan memahami kebutuhan dan keinginan dari pasar saran yang ditetapkan denga jelas, dan melakukan pemahaman ini untuk melakukan pekerjaan superior, menyampaikan kepuasan kepada para pelanggan tersebut. Keempat, konsep pemasaran berwawasan sosial yang merupkn perluasan dari konsep pemasaran dengan menekankan bahwa sebuah perusahaan seharusnya mencari menghasilkan niat baik pelanggan, tetapi harus selalu memajukan kesejahteraan sosial jangka panjang.

Kotler dan Amstrong (2008: 45-46) menyadari bahwa konsepsi tentang social capital sangat tepat dalam menuntun ilmu marketing untuk mencapai objektivitas keilmuan. Semangat objektivitas ilmu marketing adalah memenuhi kepuasan pelanggan. Hal ini tentu saja menuntut ilmu marketing untuk bisa mengidentifikasi nilai, menyediakan nilai dan menghantarkan nila kepada pelanggan. Untuk menunjukkan bahwa social capital dapat menuntun ilmu marketing mendekati objectivitas ilmu dengan menganalisis keputusan pembelian konsumen sebagai tujuan utama dari marketing. Kotler dan Keller menunjukkan bahwa dalam membuat keputusan pembelian, konsumen sering mengambil "jalan pintas mental" dengan menggunakan aturan pilihan sederhana atau yang disebut sebagai heuristik.

\section{Identifikasi Ethos dalam Manajemen Pemasaran}

Kata ethos berasal dari bahasa Yunani yang berarti etika, adat, kebiasaan, praktek Bagus 2005: 217). Evolusi logos di dalam marketing telah membawa kebaharuan dengan menekankan "relationship" sehingga jawaban yang paling memungkinkan tentang bagaimana mempertahankan keberlanjutan perusahaan adalah fokus pada social capital. Jika jawaban ini tepat dan berhak mendapat kedudukan sebagai teori ilmiah, maka ia harus mengakomodasi fakta di sekitarnya. Asumsi ini penting sebab memiliki konsekuensi pada konsepsi-konsepsi marketing pada periode sebelumnya. Konkritnya, jika seseorang menerima konsepsi social capital sebagai yang paling mumpuni maka ia berhak untuk menolak konsepsi-konsepsi sebelumnya.

Dalam kenyataanya, masih ada perusahaan yang bertahan sampai sekarang dengan mengandalkan definisi pertama, di mana fokus pada produksi barang atau berjalan satu arah, yaitu: dari produsen ke konsumen. Contoh dari perusahaan ini adalah: pabrik PC terbesar di Cina, Lenovo dan raksasa alat-alat rumah tangga Haiser. Masih ada juga perusahaan yang menekankan konsep "exchange" yang menekankan faktor penjualan dengan filosofi: menjual lebih banyak orang ke lebih banyak orang secara lebih sering untuk menghasilkan lebih banyak uang dan pada gilirannya menghasilkan lebih banyak laba. Contoh model perusahaan ini adalah coca-cola, PT. Asuransi, Ensiklopedia dan peti mati. Masih ada juga perusahaan yang mengandalkan konsep produk, yaitu dengan menawarkan kualitas, kinerja dan fitur inovatif. Konsep seperti ini memiliki jargon khusus, 
yaitu: "jika perusahaan dapat membuat jebakan tikus yang lebih baik, dunia akan membuka pintu kepada mereka" (Kotler dan Keller, 2009: 19-21).

Dengan adanya fakta seperti ini, maka kesan yang muncul adalah konsepsi tentang marketing pada periode sebelumnya bisa tidak memuaskan dan bisa memuaskan untuk periode berikutnya. Singkatnya, konsepsi tertua tentang marketing tetap relevan hingga saat-saat sekarang bahkan tetap bertahan meskipun konsepsi-konsepsi baru terus bermunculan yang tentu saja dengan ancaman ingin meruntuhkannya. Yang terpenting adalah konsep tertua tentang marketing itu bertahan karena didukung oleh fakta tertentu. Dan konsepsi yang baru juga muncul karena ingin mengakomodasi fakta di sekitarnya. Bahkan kalau dibuat perhitungan dari kaca-mata positivistik semakin banyak dan semakin sering suatu konsep mendapat konfirmasi melalui fakta di lapangan, maka seharusnya konsep marketing yang tertua berhak mendapat kedudukan sebagai teori ilmiah. Tetapi persoalannya tidak sesederhana itu, sebab munculnya teori baru juga tentu saja melihat sisi lemah teori lama hanya saja tidak berpretensi untuk menggugurkannya tetapi berusaha untuk memperkaya dengan tendensi untuk mendekati objektivitas ilmu.

Persoalan di atas tentu saja menantang marketing untuk mempertahankan kredibilitas keilmuannya. Marketing sebagai ilmu ditantang untuk menemukan konsep universal yang bersandar pada hukum-hukum empirik. Meskipun demikian, jika kita berpegang pada semangat ilmu pengetahuan yang bertolak dari rasa ingin tahu yang tinggi untuk meruntuhkan teori-teori lain yang tampak tidak logis, maka manajemen pemasaran juga berada di dalam ranah tersebut. Semangat awal berkembangnya pemasaran sebagai aktivitas dari ekonomi dipandang sebagai kegiatan yang sangat dekat dengan perilaku amoral. Hal ini dipengaruhi pemahaman teologis yang pada saat itu sangat menekankan aspek kejiwaan. Bahwasannya, aktivitas bisnis akan menggiring orang untuk hanya mengejar kekayaan duniawi lalu mengabaikan kehidupan jiwanya. Di dalam semangat yang bersebrangan dengan pandangan teologis, bisnis terus berkembang dengan logika sekuler.

Adanya kesan problematis ini tentu saja memandu kita untuk mempertimbangkan pendapat Imre Lakatos tentang teori yang matang dan teori yang belum matang. Lakatos sebagaimana dikutip Poepowardojo dan Seran (2016: 114-115) menyebutkan bahwa sebuah teori dikatakan berkembang manakala ada upaya penemuan fakta baru melalui pembuktian matematis. Sebab tujuan pengembangan teori ilmiah adalah untuk melindungi gagasan umum atau inti pokok program (hard core) dari hipotesis pelengkap (auxiliary hypotheses). Sebab, inti-pokok program (Hard-core) merupakan sesuatu yang menentukan karakteristik suatu program, yakni sebagai hipotesa teoritis umum yang menjadi dasar program yang akan dikembangkan.

Ilmuan marketing modern menunjukkan bahwa social capital merupakan inti pokok program (core business). Studi ini berdiri di atas proposisi: "Perusahaan akan berupaya untuk mendapatkan tempat yang baik dalam posisi keunggulan bersaingnya dengan secara efektif mendayagunakan berbagai elemen modal sosialnya. Portofolio modal sosial yang dibangun dari jejaring sosial, rasa dipercaya, kepatuhan pada norma sosial dan norma resiprositas dan berbagai kohesi sosial serta kerjasama sinergis yang dibangun akan menghasilkan sumber daya yang khas perusahaan (company-specific resources) yang memiliki potensi untuk meningkatkan keunggulan bersaing perusahaan. Semakin tinggi 
derajad kekhasan perusahaan atas modal sosialnya, semakin tinggi derajad keunggulan bersaing yang dimilikinya (Ferdinand, 2013).

Beberapa kesimpulan yang dapat ditarik dari pengembangan aplikasi konsep modal sosial tersebut adalah : Pertama, modal sosial pada dasarnya adalah modal yang dapat dibangun dengan investasi yang rendah tetapi menuntut kesinambungan investasi untuk menjamin keberadaannya sebagai sebuah "isolating mechanism" untuk memberi peluang bagi tumbuh dan berkembangnya keunggulan bersaing. Kedua, modal sosial berkembang dan melekat secara sosial historis dalam mekanisme manajemen sehari-hari sehingga bersifat khas perusahaan-firm-specific, oleh karena itu sulit ditiru dan berpotensi menghasilkan keunggulan bersaing yang berkelanjutan. Ketiga, modal sosial relatif mudah dijangkau, bebas pajak, dapat disimpan dalam perusahaan, tetapi tidak mudah pengembangannya karena ia menuntut sentuhan-sentuhan sosial yang intens dan berkelanjutan (Ferdinand, 2013).

\section{Identifikasi Pathos dalam Manajemen Pemasaran}

Jauh sebelum marketing berkembang sebagai konsepsi ilmiah, masyarakat sudah mengenalnya sebagi seni dalam berdagang untuk menghasilkan laba. Dalam pengertian ini, barang sudah tersedia dan tugas pedagang adalah mempengaruhi orang untuk bisa membeli dengan harga tertentu. Kendalanya adalah pedagang harus berusaha semaksimal mungkin agar barang itu beralih ke tangan pembeli. Sehingga pedagang tak jarang menggunakan cara yang tidak etis termasuk tipu daya untuk menghasilkan laba yang tinggi.

Filosofi dagang inilah yang kemudian mendasari elemen-elemen marketing lainnya seperti pendistribusian, penjualan dan pengiklanan. Kotler dan Keller (2009: 29) menyebutkan bahwa ketika pemasar berkonsentrasi pada proses produksi, maka strategi yang digunakan adalah mendistribusikan barang. Dengan konsep ini, pemasar berasumsi bahwa pelanggan memiliki minat beli dan daya beli yang tinggi sehingga pemasar hanya memerlukan waktu dan sedikit tenaga untuk mendistribusikan barang tersebut. Berbeda dengan pemasar yang berkonsentrasi dengan kualitas produk, tentunya strategi yang digunakan adalah selling. Persoalan yang sering muncul dari strategi ini adalah banyak terjadi penipuan berupa kemasan atau merk. Kotler (2009: 19) menyebut ini dengan istilah "jebakan tikus". Hal yang berbeda pula terjadi ketika pemasar menggunakan strategi advertising. Strategi ini menyasar kebutuhan yang tidak terpikirkan oleh pelanggan. Persoalan yang sering muncul adalah pelanggan sering tidak mengetahui mekanisme dari produk tersebut. Banyak kasus yang terjadi, misalnya pada perusahaan asuransi dimana pelanggan sangat mengalami kesulitan ketika mengklaim dana asuransi yang mana mekanismenya berbelit-belit sehingga kadang ada pelanggan yang tidak berhasil membuat klaim padahal sudah banyak menginvestasikan dananya.

Baik distibution, selling maupun advertising adalah beberapa elemen penting dalam pemasaran yang mutlak perlu dilakukan ketika perusahaan telah mengenali betul segmen pasar sasarannya. Persoalannya banyak perusahaan yang sering bekerja hanya berdasarkan anggapan umum (common sense). Hanya dengan asumsi umum, perusahaan memproduksi barang kemudian menyalurkan barang kepada pelanggan. Jika pelanggan sensitif terhadap harga atau mengalami resesi, maka diberlakukan diskon yang alih-alih hanya memperdaya konsumen. Ketika muncul perusahaan lain yang menerapkan strategi relationship dengan 
filosofi social capital, maka perusahaan yang hanya mengandalkan common sense tentunya akan kalah bersaing karena pelanggan akan beralih.

Kotler dan Keller (2009: 135-139) menyebutkan bahwa seni pemasaran adalah seni mengidentifikasi nilai, menyediakan nilai dan mengkomunikasikan nilai. Dengan membangun argumentasi seperti ini, Kotler dan Keller sesungguhnya ingin membalikkan logika sebelumnya yang menempatkan common sense pada perusahaan dengan menempatkannya pada konsumen. Artinya, yang sering membuat keputusan pembelian dengan anggapan umum adalah konsumen bukan perusahaan. Perusahaan seharusnya membuat keputusan yang tepat mengingat dia memiliki tujuan untuk mengikat pelanggan dalam jangka waktu yang panjang dan selalu dihadapkan pada persaingan dengan perusahaan lain. Dengan mengenali kebutuhan pelanggan, maka perusahaan akan dengan mudah menentukan core business (kekhasan perusahaannya) dan menciptakan banchmarking.

Tantangan terberat dari pemasar adalah memahani kebutuhan dan keinginan pelanggan. Sebagian pelanggan memiliki kebutuhan yang tidak sepenuhnya mereka sadari atau mereka tidak dapat mengartikulasikan kebutuhan ini. Karena itu, pemasaran harus pandai-pandai menginterpretasi kebutuhan pelanggan. Kotler dan Keller (2009: 13) membedakan kebutuhan dalam lima tipe, antara lain:

1. Kebutuhan yang dinyatakan (artinya pelanggan menginginkan mobil yang murah).

2. Kebutuhan yang sebenarnya (artinya pelanggan menginginkan sebuah mobil yang biaya operasionalnya, bukan harga awalnya rendah).

3. Kebutuhan yang tidak dinyatakan (artinya pelanggan mengharapkan pelayanan yang baik dari dealer mobil).

4. Kebutuhan kesenangan (artinya pelanggan ingin agar dealer mobil juga memasukkan sistem navigasi ke dalam paket).

5. Kebutuhan rahasia ( artinya pelanggan ingin agar temannya memandang dirinya sebagai pelanggan yang cerdas).

Pembedaan kebutuhan ini mutlak perlu sebab bisa saja pemasar telah melayani kebutuhan pelanggan padahal tidak memberi apa yang benar-benar dibutuhkannya. Banyak konsumen yang tidak tahu apa yang mereka inginkan dalam sebuah produk. Memberi pelanggan apa yang mereka inginkan tidak lagi cukup. Untuk memperoleh keuntungan, perusahaan harus membantu pelanggan dalam mempelajari apa yang mereka inginkan.

\section{Kontribusi Budaya terhadap Ilmu Marketing}

Ilmu marketing sebagai ilmu yang sangat empirik, teknis dan praksis tentunya hanya bisa berkembang oleh karena kontribusi budaya tertentu. Hal ini dikarenakan ilmu marketing berurusan dengan kebutuhan manusia yang paling praktis. Ada sejumlah kontribusi budaya terhadap ilmu marketing, misalnya (Kotler dan Keller, 2009: 103): perusahaan motorola mengembangkan telepon seluler A732, dimana pengguna dapat menulis secara langsung di atas keypad dengan menggunakan jari. Setelah mempelajari cara orang mendengarkan musik, membaca majalah dan menonton TV, Sirus mengembangkan pemutar radio-satelit portabel yang mudah diisi dengan musik digital sampai 50 jam untuk diputar di lain waktu.

Dengan orientasi pada pelanggan ilmu marketing menemukan bahwa ada sejumlah nilai yang dibutuhkan oleh pelanggan seperti: kemudahan, kecepatan dan ketepatan. Karena 
itu produksi teknologi sekarang lebih mengutamakan nilai-nilai tersebut karena bisa meningkatkan loyalitas pelanggan. Hal ini tercermin dari penciptaan merk (branding) sehingga membuat pelanggan seumur hidupnya. Karena itu, dapat dikatakan bahwa majumundurnya ilmu marketing sangat ditentukan oleh budaya tertentu. Budaya mempengaruhi marketing untuk membuat keputusan yang tepat dan dapat meramalkan keberlanjutannya secara jangka panjang. Perusahaan yang kini mengembangkan social capital juga sematamata karena dipengaruhi oleh perkembangan budaya di dalam masyarakat. Sebagaimana budaya yang sangat fleksibel, demikian pula ilmu marketing sangat fleksibel. Penciptaan inovasi tidak lain adalah untuk menjawab kebudayaan masyarakat yang terus berkembang dari saat ke saat.

\section{Simpulan}

Sekalipun keilmuan manajemen pemasaran belum kokoh sebagai teori yang tahan uji, namun harus diakui dimensi keuniversalan yang dicapai, yaitu: (1) Ilmu manajemen pemasaran menunjukkan keilmiahannya melalui prosedur ilmiah untuk mengontruksi modal sosial sebagai kebenaran universal, menciptakan skema keberlanjutan jangka panjang melalui komunikasi dua arah: pelanggan-perusahaan dan terus mentransformasi nilai untuk mengikat pelanggan. (2) Dengan menjadikan modal sosial sebagai logos universal, ilmu manajemen pemasaran menunjukkan bahwa tidak ada metode tunggal dalam pencapaian objektivitas. Berbagai penelitian ilmiah yang menghasilkan kesimpulan kontradiktif bukan saling menggugurkan tetapi semata-mata hanya menempuh paradigma yang berbeda. Jadi, fleksibelnya ilmu pemasaran menghendaki adanya multi metode ilmiah karena berporos pada dinamika kebutuhan pelanggan.

\section{Daftar Pustaka}

Bagus, Lorens. 2005. Kamus Filsafat. Penerbit PT Gramedia Pustaka Utama. Jakarta Ferdinand, Augusty Tae. 2005. Modal Sosial Dan Keunggulan Bersaing: Wajah Sosial Strategi Pemasaran. PIDATO PENGUKUHAN Disampaikan pada Upacara Penerimaan Jabatan Guru Besar dalam Ilmu Marketing pada Fakultas Ekonomi Universitas Diponegoro Semarang: Badan Penerbit Universitas Diponegoro Semarang.

Kotler, Philip dan Garry Amstrong. 2008. Prinsip-Prinsip Pemasaran. Jilid I, edisi 12.

Bob Sabran (Penerjeman). Jakarta: Gelora Aksa Pratama.

Kotler, Philip dan Kevin Lane Keller. 2009. Manajemen Pemasaran. Jilid I, edisi 13. Bob

Sabran (Penerjeman). Jakarta: Gelora Aksa Pratama.

Lukitaningsih, Ambar. 2013. Perkembangan Konsep Pemasaran: Implementasi Dan

Implikasinya. "Jurnal MAKSIPRENEUR". Vol. III, No. 1, Hal 21-35

Poepowardojo, T. M. Soerjanto dan Alexander Seran. 2016. Filsafat Ilmu Pengetahuan, Hakikat ilmu Pengetahuan, Kritik terhadap Visi Posotivisme Logis dan Implikasinya. Jakarta: Kompas.

Setyawan, Anton Agus. 2012. Menuju Sebuah Teori Umum Pemasaran. BENEFIT “Jurnal Manajemen dan Bisnis" Volume 16, Nomor 1, Juni 2012, hlm. 1-9 